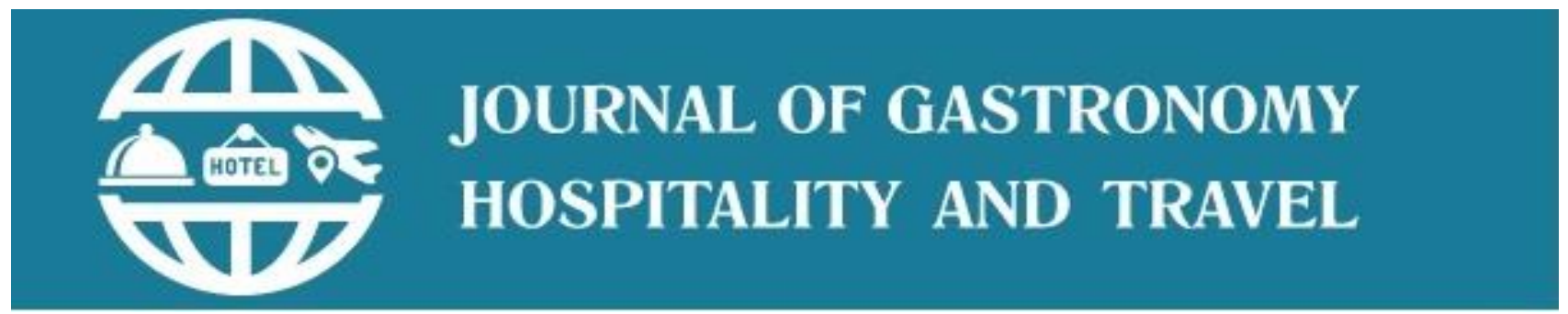

ISSN: 2619-9548

Journal homepage: $\underline{w w w . j o g h a t . o r g, ~} \underline{\text { http://dergipark.gov.tr/joghat }}$

Journal of Gastronomy, Hospitality and Travel (JOGHAT)

2020 - Volume: 3 Number: 1

Page : 101-111

Received: 05/05/2020

Revised:11/06/2020

Accepted: $12 / 06 / 2020$

\title{
Research Article \\ PERCEPTIONS AND PRACTICE OF TIPPING AMONGST DOMESTIC TOURISTS IN ZIMBABWE
}

\author{
*Precious Mazhande1 (orcid.org/0000-0001-7801-4531) \\ *^Vitalis Basera (orcid.org/0000-0002-0705-5974) \\ ^Oliver Chikuta (orcid.org/0000-0003-1947-8584) \\ *Musawenkosi Tapfuma (orcid.org/0000-0003-3419-4176) \\ *Felicity Ncube (orcid.org/0000-0003-2074-9054) \\ ${ }^{* \wedge}$ Rudorwashe Baipai (orcid.org/0000-0001-7489-0630) \\ *Department of Tourism and Hospitality Management, Midlands State University, Zimbabwe \\ ${ }^{* \wedge}$ Department of Tourism and Hospitality Management, MSUAS, Zimbabwe \\ $\wedge^{\wedge}$ Faculty of Hospitality and Sustainable Tourism, BOTHO University, Botswana
}

\begin{abstract}
Tipping is a common practice globally and at times mandatory in some societies, at the same time, some communities regard tipping as taboo. African societies view tipping differently and this poses a challenge among international tourists, particularly those from the west who are used to expressing their gratitude towards a satisfactory service through giving a tip. While it is almost certain that some nationals will always give a tip, do Africans, particularly Zimbabweans subscribe to the tipping philosophy? There is not enough literature in academia on tipping amongst African tourists, particularly those in Zimbabwe. Preliminary review of literature has revealed that there are only two studies published on the tipping practice in Zimbabwe. The one focused on the impact of tipping on waiters' service delivery as well as working relations among waiting staff (Mkono, 2011). The other study looked at the perceptions of hotel employees towards tipping and motivation (Kazembe, Mapingure \& Chimutingiza, 2014). It is evident that the published studies were all supply side oriented without considering the demand side. This study seeks to interrogate the demand side by; (i) establishing the perceptions of domestic tourists when it comes to tipping; (ii) expose the nature of tipping amongst local tourists; (iii) establishing the motivation for tipping amongst domestic tourists. The study adopted a phenomenological philosophy, and used a qualitative design to collect and analyze data. The study conveniently sampled forty (40) domestic tourists from four (4) hotels in Zimbabwe and interviewed them. The findings revealed that domestic tourists in Zimbabwe perceive tipping as an appropriate and good practice. The main form
\end{abstract}

\footnotetext{
${ }^{1}$ To cite this document: Mazhande, P., Basera, V., Chikuta, O., Tapfuma, M., Ncube, F. and Baipai, R. (2020). Perceptions and Practice of Tipping amongst Domestic Tourists in Zimbabwe, 3(1), 101-111. DOI: 10.33083/joghat.2020.34

Corresponding Author: preciousmazh@gmail.com
} 
of tipping indicated in the study is the monetary. The study also found out that the motivations for tipping are as varied as the people who practice it.

Keywords: Perceptions, Tipping, Domestic Tourists

\section{Introduction}

This study sought to interrogate the demand side by; (i) establishing the perceptions of domestic tourists when it comes to tipping; (ii) expose the nature of tipping amongst domestic tourists and; (iii) establishing the motivation for tipping amongst domestic tourists. Different authors have defined and explained the concept of tipping differently. There is no conflict on the general existence of the practice, but the aim, motives and reasons of tipping are still vague from both the supply and demand side. Tipping is now generally practiced in service industry than before, where it was only in restaurant (Lynn \& Withiam, 2008; Lynn, 2016; Lynn \& Brewster, 2019). The following are some of the definitions given for tipping; Lynn, et al., (1993) simply expressed a tip as an extra amount of income given to service providers by customers after getting a service or before they leave. A tip is voluntary gift of money given in appreciation for service received and retained by the person given the tip (Saayman \& Saayman, 2015). Kazembe \& Mapingure, (2014) defined tipping as an incentive that motivates servers to put an extra effort at providing a good service in the restaurant. It is a voluntary deliberate behavior and social standard aimed to ensure better forthcoming service (Jahan, 2018; Shatnawi, et al., 2019; Lynn, 2016). Common amongst these definitions is the element of voluntary giving as well as an attachment of the gift to a service, either rendered or anticipated in the future. Tipping has an economic value with inferences in spheres of economics and management of tourism businesses. In USA; 3 million out of the 4.7 million food servers employed earn part of their income from tips (Azar, 2010). In USA it generates an estimated US $\$ 40$ billion per year and in Canada it is estimated at US\$27 billion (Lynn, 2016).

Many researchers investigated and tried to answer the question why people tip (Azar, 2010; Casey, 2001; Kruger \& Saayman, 2016, Lynn, 2016) and findings in USA, Malaysia and South Africa restaurants were related but different motives and reasons for tipping were given. Tipping differs amongst countries and cultures (Zahari, et al., 2011) and it is broadly practicesed in the service industry (bars, taxis, restaurants, doormen, musicians, parking valets). To get an understanding of perceptions and practice of tipping amongst tourists, fifteen publications on tipping were purposefully considered from developed and developing countries. The reviewed publications were published between 2010 and 2019. In Zimbabwe only two publications have been published on tipping. Table 1 summarises the publications that were analysed.

Table1: Publications on Tipping

\begin{tabular}{l|l|l|l}
\hline Authors & Paper title & Side & Country \\
\hline $\begin{array}{l}\text { Kazembe \&apingure, \& } \\
\text { 2014 }\end{array}$ & $\begin{array}{l}\text { The perceptions of employees towards } \\
\text { tipping and motivation in the hotel } \\
\text { industry }\end{array}$ & Supply side & Zimbabwe \\
\hline $\begin{array}{l}\text { Raspor \& } \\
\text { Rozman, 2016) }\end{array}$ & $\begin{array}{l}\text { Impact of tipping on workers' } \\
\text { motivation: Comparison between the } \\
\text { hospitality and gaming industries in } \\
\text { Slovenia }\end{array}$ & Supply side & Slovenia \\
\hline $\begin{array}{l}\text { Kruger \& } \\
\text { Saayman, 2016 }\end{array}$ & $\begin{array}{l}\text { The dining and tipping behaviour of } \\
\text { Black South Africans: A segmentation } \\
\text { approach }\end{array}$ & Demand Side & $\begin{array}{l}\text { South } \\
\text { Africa }\end{array}$ \\
\hline $\begin{array}{l}\text { Saayman \& } \\
\text { Saayman, 2015 }\end{array}$ & $\begin{array}{l}\text { To tip or not to tip? } \\
\begin{array}{l}\text { Lee \& Dewald, } \\
\text { 2016 }\end{array}\end{array} \begin{array}{l}\text { Tipping practices of Chinese tourists in } \\
\text { U.S. restaurants: An exploratory study }\end{array}$ & Demand side & $\begin{array}{l}\text { United } \\
\text { States }\end{array}$ \\
\hline Lynn, 2016 & $\begin{array}{l}\text { Service gratuities and tipping: A } \\
\text { motivational framework }\end{array}$ & $\begin{array}{l}\text { Demand-Supply } \\
\text { Side }\end{array}$ & $\begin{array}{l}\text { United } \\
\text { States }\end{array}$ \\
\hline
\end{tabular}




\begin{tabular}{|c|c|c|c|}
\hline Azar, 2010 & $\begin{array}{l}\text { Do people tip because of psychological } \\
\text { or strategic motivations? An empirical } \\
\text { analysis of restaurant tipping }\end{array}$ & Demand Side & $\begin{array}{l}\text { United } \\
\text { States }\end{array}$ \\
\hline $\begin{array}{l}\text { Zahari, et al., } \\
2011\end{array}$ & $\begin{array}{l}\text { Tipping has it becoming a prevalent norm } \\
\text { in Malaysia hospitality industry }\end{array}$ & $\begin{array}{l}\text { Demand-Supply } \\
\text { Side }\end{array}$ & Malaysia \\
\hline Nusrat, 2018 & $\begin{array}{l}\text { Determinants of Tipping Behavior: } \\
\text { Evidence from US Restaurants }\end{array}$ & Supply Side & $\begin{array}{l}\text { United } \\
\text { States }\end{array}$ \\
\hline $\begin{array}{l}\text { Shatnawi, et al., } \\
2019\end{array}$ & $\begin{array}{l}\text { Factors affecting customers' behavior } \\
\text { towards tipping intentions in Jordanian } \\
\text { restaurants }\end{array}$ & Supply Side & Jordan \\
\hline $\begin{array}{l}\text { Whaley \& } \\
\text { Costen, } 2019\end{array}$ & $\begin{array}{l}\text { Personal and social tipping norms: race } \\
\text { and sex differences }\end{array}$ & Supply side & $\begin{array}{l}\text { United } \\
\text { States }\end{array}$ \\
\hline Lynn, 2016 & $\begin{array}{l}\text { The business case for (and against) } \\
\text { restaurant tipping }\end{array}$ & Demand side & $\begin{array}{l}\text { United } \\
\text { States }\end{array}$ \\
\hline $\begin{array}{l}\text { Saayman } \& \\
\text { Saayman, } 2015\end{array}$ & $\begin{array}{l}\text { Understanding tipping behavior }- \text { an } \\
\text { economic perspective }\end{array}$ & Supply side & $\begin{array}{l}\text { South } \\
\text { Africa }\end{array}$ \\
\hline Mkono, 2011 & $\begin{array}{l}\text { Tipping practices and policies in } \\
\text { Zimbabwe's hotel industry: Impacts on } \\
\text { restaurant waiters' service deliver and } \\
\text { work relationships. }\end{array}$ & Demand side & Zimbabwe \\
\hline $\begin{array}{lr}\text { Lynn } & \& \\
\text { Brewster, } 2019\end{array}$ & $\begin{array}{l}\text { The tipping behavior and motives of US } \\
\text { travelers abroad: affected by host } \\
\text { nations' tipping norms? }\end{array}$ & $\begin{array}{l}\text { Supply-Demand } \\
\text { Side }\end{array}$ & $\begin{array}{l}\text { United } \\
\text { States }\end{array}$ \\
\hline
\end{tabular}

Motives and reasons for tipping vary; Saayman and Saayman (2015) gave social approval, equitable service exchange and other reasons when they asked: What influences the frequency of tipping decisions?, What influences the magnitude of the tip given?, and Who is likely to tip more than the norm? as they investigated tipping behaviour from an economic perspective in South Africa. The findings reviewed that the ability to pay tip determines tipping frequency and its magnitude. Lynn and Brewster (2019) pointed out that forthcoming service is not the most important motivation for tipping, people tipp to obey to social norms and get social acceptance. Reasons for tipping workers is that it has become a social norm and there is need to conform to social norms and get social approval (Lynn \& Brewster, 2019, Lynn, 2008, Saayman, 2014).

Tips are given as a kind of assistance to low income earners, as means to express generosity, and expression of superiority (Azar, 2010). The need to have better service in the future, companionship, food quality and level of service are some of the reason why Chinese tourist tip in American restaurants (Lee \& Dewald, 2016, Jahan, 2018). According to Shatnawi, et al., (2019) in Jordan restaurants food quality and service quality are the most important reasons creating tipping intentions, older age groups and the groups that had regular visits to restaurants had more intents to pay tips. Race and sex of the either the server or the client, group size, payment method, friendly of the staff and cost of the meal also motivates tipping, African- American man do not consider tipping whether for poor, mediocre or excellent service (Whaley \& Costen, 2019, Kim, Nemeschanky \& Brandt, 2019). Zahari, et al., 2011 conceptualised the reason for tipping as; socio demographic and behavioural aspects of the customer, the server and external factors (weather and location).

Tip payment takes different forms; a tip can be added to the bill as fixed service charge, or discretionary tipping, where customer making a descritionary decision to pay direct to the servers. Discretionary tipping can either be given to the individual server or pooled (sharing tips equally) (Saayman \& Saayman, 2015; Saayman, 2014). Mkono (2011), Kazembe and Mapingure (2014) noted that in Zimbabwe discretionary tipping is the norm and many hotels use tip-pooling system which is deemed unfair by most waiters. Service charges are not popular.

Tipping and tipping alternatives of service charges and service inclusive pricing was analysed by Lynn and Withiam (2008) and noted some advantages and disadvantages of tipping. The major benefits of tipping were 
reduced nominal pricing, increase in profits,retention of skilled worker, spurs up selling and service and lowers tax payment. The demerits of tipping were resultant in discrimination service delivery and reduction of firms's profits as that extra income is taken by servers. The absence of tip has consequences to human resources turnover, social economics and worker discrimnation by gender (Kazembe \& Mapingure, 2014). Mkono (2011) bemoans stereotyping as negative impact of tipping, talking and regarding customers in a stereotypical way is not acceptable. There is no one remedy to challenges of tipping and tipping alternatives.

\subsection{Characterisation of domestic tourists}

United Nation World Tourism Organistion (UNWTO) in 2005 defined a domestic tourist as any person residing in a country who travels to a place within the country, outside his or her usual environment for a period not exceeding twelve months. The term domestic tourism refers to journeys "journeys and visists within a person's home country" (Singh, 2009). Mapingure, et al., (2019) in their study of domestic travel motivations simply expressed domestic tourism as the activities of resident visitors within the country of reference. Domestic tourism is stable in many developing nations and is not that sensitive to international trends of terrorism, global financial crisis and politics. Domestic tourist constitute a big population staying in hotels and using tourism facilities (Kabote, et al., 2017). Domestic tourism is important for job creation, poverty alleviation, creation of business opportunities, infrastructure development, it provides reliable market through out the year and overall controbution to gross domestic product (Makhaola \& Proches, 2017).

The travel motivations of domestic tourists in Zimbabwe are unique and they range from nature, novelty and escape (Mapingure, et al., 2019). Novelty dominates the motivation to travel amongst most Zimbabwean which is a confirmation that most locals lacks exposure to their own resources. Socio and demograohic components of the study by Mapingure, et al., (2019) reviewed that most of the people who participate in domestic tourism were low income earners. Domestic tourists travel during school and public holidays with limited time from work. Zakaria and Aziz (2018) in their study to determine domestic tourist satisfaction in Kuala Selangor found out that most visistors were satisfied with heritage, historical and cultural attractions while nature was the least satisfactory attraction. Domestic tourists were not very much impressed with shopping, cuisine, sport, and adventure attractions. Destination image, range of services to tourists and quality of humann interaction to tourist impact domestic tourists satisfaction and loyalty to destianation (Herle, 2018, Zakaria \& Aziz, 2018).

Kabote and Mutsena, (2013) noted that in Zimbabwe, the Indigenisation policy, Land reform policy and other fiscal and monetory polies have significantly affected domestic tourism perfomance in the country, with people expressing disssatisfaction as these policies have significantly eroded their disposable income thereby decreasing their propensity to engage in domestic travel. Domestic tourism is still low in the country as the industry still relies heavily on the international tourists (Basera, 2018).

In Zimbabwe domestic tourists enjoy least priced products, discounts, differentiated pricing and price bundling. They are are extremely price sensitive (Kabote, et al., 2017). Majority of Zimbabweans are low to middle income earners and very literate on prices, yet studies have revealed that $41 \%$ of the decision to participate in domestic tourism is affected by price while $59 \%$ of the decision is affected by time, income, environment and support for domestistic tourism (Kabote, et al., 2019). The domestic tourism in Zimbabwe occurs at anchor attractions like Victoria falls, Great Zimbabwe monuments and also in small towns that are endowed with natural and man-made beauty (Kanokanga, et al., 2014). Kabote, et al., (2019) analysed the domestic tourist travel trends in Zimbabwe and came up with six major trends. Domestic tourists prefer established destiantions and little known destinations, secondly they connect to destinations using own cars, walking, train, cbuses, taxis and airplanes and thirdly they prefer destinations that offer many activities such as sports, adrenaline and nature activities. Domestic tourists also travel in groups as families, friends, and workmates and lastly, they are low spenders on art craft works.

\section{Methodology}

The study adopted a phenomenological philosophy, and used a qualitative design to collect and analyze data. The study conveniently sampled forty (40) domestic tourists from four (4) hotels in Zimbabwe. Ritchie and Lewis. (2003) stipulated that qualitative samples are usually fewer than fifty. Semi structured interviews were used to collect data from Zimbabweans who had spent at least one night at the chosen hotels in Bulawayo, 
Mutare, Harare and Victoria Falls. Semi structured interviews provide in-depth contextualised insights (Gorton, 2000; Zahra, 2007). Questions asked in the interview included the following:

Table 2: Interview questions

\begin{tabular}{|l|}
\hline What do you understand by term tipping? \\
\hline Have you ever tipped for any service you got in a hospitality establishment? \\
\hline Do you think tipping is necessary? \\
\hline How often do you tip and how? \\
\hline Who should get tipped? \\
\hline Do you think a tip can be in any other form than money? \\
\hline What factors do you think influence your decision to tip or not? \\
\hline What is your overall opinion about tipping in general? \\
\hline
\end{tabular}

All the hotels offer rates that are inclusive of bed and breakfast, hence there was definitely some interactions between the tourists and service staff either at the front office, restaurant, bar or room service. These are usually the points where tipping takes place. The study did not discriminate between business and leisure tourists since both are categories of domestic tourists. Notes were taken during the interviews, which were later organized into themes and analysed.

\section{Results and Discussions}

\subsection{Demographic Data}

All the targeted 40 interviews were conducted successfully giving a 100\% response rate. In terms of gender $76 \%$ males participated against $24 \%$ for females. The majority of the respondents were guests who were on business and $20 \%$ had travelled for leisure. Table 2 below summarises the respondents' profile:

Table 3: Respondents' Profile

\begin{tabular}{|l|l|l|}
\hline Respondent Profession & Purpose of Visit & Room Package \\
\hline 15 Corporate Managers & Business & Bed \& Breakfast \\
\hline 6 Entrepreneurs & Leisure & $\begin{array}{l}\text { Dinner, Bed \& } \\
\text { Breakfast }\end{array}$ \\
\hline 3 Politicians & In transit & Bed only \\
\hline 2 Council Employees & Strategic Meeting & Bed \& Breakfast \\
\hline 2 Lecturers & Attachment Visit & Bed \& Breakfast \\
\hline 2 Primary School Teachers & Business seminar & $\begin{array}{l}\text { Conference teas \& } \\
\text { Lunch }\end{array}$ \\
\hline 1 Medical Practitioner & Leisure & $\begin{array}{l}\text { Dinner, Bed \& } \\
\text { Breakfast }\end{array}$ \\
\hline 1 Geologist & & Bed \& Breakfast \\
\hline 5 Farmers & Business & Bed \& Breakfast \\
\hline 3 Pastors & Leisure \& Business & Bed \& Breakfast \\
\hline
\end{tabular}


Using thematic analysis the following results emerged from the interviews

\subsection{Perceptions of Domestic Tourists on the Tipping Practice}

The first objective sought to establish the perceptions of domestic tourists when it comes to tipping. All the respondents were familiar with tipping.

Respondent 10 noted:

"Tipping is an act of kindness towards service employees"

The respondent was of the view that giving a tip is a sign of kindness. In other words this means that the respondent felt that there is need to be kind towards service employees. This concurs with Azar,( 2010) who highlighted that tipping is a means to express generosity,

Another respondent 18 highlighted the following:

"Tipping is a thank you for a good service"

From the above response it can be noted that the respondent is implying that only good service should be rewarded. This resonates with Kazembe \& Mapingure, (2014)'s definition of tipping which looks at it as an incentive that motivates servers to put an extra effort at providing a good service in the restaurant.

\section{Tipping as a necessity}

95\% of the respondents indicated that tipping is necessary. One respondent noted that:

"Tipping is necessary as it helps supplement hotel employee's salaries"

The above respondent has the perception that employees in the hotel industry are lowly paid so it is necessary to give them tips. Tips are given as a kind of assistance to low income earners, as means to express generosity, and expression of superiority (Azar, 2010). One would be interested to know whether the same participants were indeed giving a tip, it is one thing to say it, but another to do it.

However $5 \%$ of the respondents were of the view that it is not necessary to give tips. Respondent 8 indicated the following: "It is not necessary to give tips because it is an unfair practice. Only the exposed staff members are privy to tips yet there are also people behind the scenes like the chefs. "From the above response it can be noted that the respondent feels that tips are only being given to those in direct contact with the guests leaving those at the back of the house. One may want to concur and argue that good service is a function of many factors and players. While the waiter/waitress may exhibit excellence etiquette, that would not be enough without the expertise of the people preparing the dishes. This could perhaps be the reason why some hotels prefer to pool the tips and share them equally.

One government employee felt that tipping is not necessary and was quoted saying "Why should I tip I am employed by the government, my salary is very low I am just a civil servant". Another Corporate Manager who works in a bank had the following to say" I do not think it necessary to tip because some of us are on company accounts and everything has been paid for, I do not have any money on me". From the above findings it can be derived that domestic tourists who are on leisure tend to tip more often than those on company business as companies do not give allowances for tipping, however individuals tend to dig deep in their pockets and tip.

\section{Overall view on tipping}

All the interviewees indicated that tipping generally a good practice in the service industry. One enthusiastic business traveler had the following to say: "I will equate tipping to greasing a moving part of a vehicle. This is done to allow efficiency before you encounter problems" His line of thinking was that if service employees are given tips they are being greased for perfect service delivery. However another respondent had a different view and said the following:" Tipping is a good practice but in Zimbabwe I do not think it is serving the intended purpose of motivating service employees. Instead you realize that some of the establishment were we give tips they end up taking guests for granted and relax on offering excellent service".

\subsection{Nature of Tipping amongst Domestic Tourists}


The second objective sought to expose the nature of tipping amongst local tourists and the following emerged. Twenty percent $(20 \%)$ of the respondents were of the view that tips should only be in the form of money. One respondent indicated the following:

"I think tips should only be in the form of money because it is easier to quantify, one can simply say I want to give a certain percentage of the bill as a tip"

However eighty percent (80\%) of the respondents felt that tips should take any other form than money. As noted by one female respondent:

"A tip can take any form. One can decide to buy food or drinks for the service employee or sometimes even give things like jewelry and clothes"

Both the above views are in line with Saayman \& Saayman, (2015) \& Saayman, (2014) who postulates that tips takes different forms; a tip can be added to the bill as fixed service charge, tipping (customer making a descritionary decision to pay direct to the server) and a pool tipping (sharing tips equally)

\section{Factors influencing the decision to tip}

Respondents were asked what factors influence their decision to tip and the following themes emerged: Attitude of the server, Availability of money or token; Guest perception of the service employee

All the respondents indicated that the attitude of the service employee influenced their decision to tip. A friendly and courteous employee automatically influences their decision. Seventy percent (70\%) of the respondents highlighted that the availability of money or a token acted as an influencer to tipping. Guests are driven by the amount of disposable income they have to give as a tip. One respondent indicated that his perception on the service employee influences his decision to tip. If he feels that the employee is a hard worker but is not well remunerated that acts as an influencer on his decision to tip. The above findings concue with Zahari, et al., 2011 who conceptualised the reason for tipping as; socio demographic and behavioural aspects of the customer, the server and external factors

\subsection{Motivation of tipping amongst domestic tourists}

The third objective sought to establish the motivation of tipping amongst local tourists. Four key themes emerged on the motivation for tipping and these were: Appreciating good service; instigating priority service; motivating service employees and supplementing salaries. These were presented in accordance with the frequency of citation:

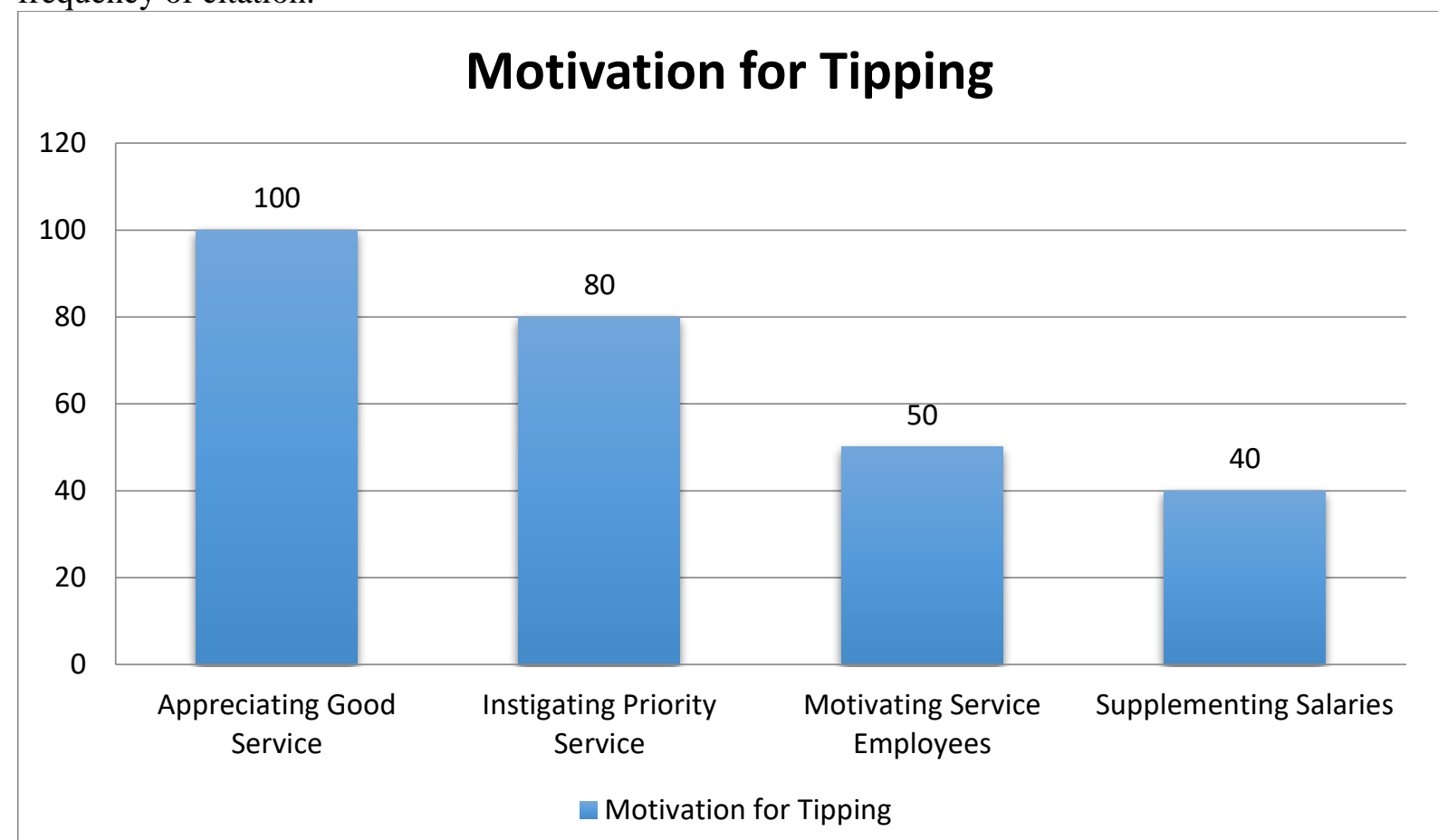

Motivation for tipping 


\section{Appreciating Good Service}

All the respondents indicated that they have tipped as a way to appreciate good service rendered by the hotel employees. Below is an extract of what one of the respondents had to say: "At one point I tipped at a restaurant because the waiter was friendly, attentive and knowledgeable"The above response supports the findings of Shatnawi, et al., (2019) who observed that in Jordan restaurants food quality and service quality are the most important reasons creating tipping intentions. The quality of service is more important regardless of how much the guest is spending.

\section{Instigating priority service}

Eighty percent (80\%) of the respondents perceived that instigating priority service is a motivator for tipping. One business traveler had the following to say: "Tipping is necessary as it promotes good \& timely attention at a later stage. Next time I use their service again I will be treated differently". The findings are in line with Lee \& Dewald, (2016) and Jahan, (2018) who identified the need to have better service in the future, companion, food quality and level of service as motivating Chinese tourist to tip in American restaurants.

\section{Motivating service employees}

Fifty percent $(50 \%)$ of the respondents indicated that they tipped as a way to motivate service employees. A couple on honeymoon indicated the following: "Hotel employees need tips as they act as a motivator. It pushes them to go an extra mile for us and they will feel appreciated." Kazembe \& Mapingure, (2014) defined tipping as an incentive that motivates servers to put an extra effort at providing a good service in the restaurant.

\section{Supplementing Salaries}

Forty percent (40\%) of the respondents revealed that they tip as a way to supplement salaries of hotel employees. Respondents indicated that they tip in a bid to help balance the finances of the hotel employees as they are deemed to be lowly paid. One would wonder how these guests know the salaries that are being paid to waiting staff. Perhaps the guest either work in the hospitality industry or have relatives who are employed in the sector. It is however a globally known fact that hotel service staff are amongst employees who are lowly paid despite their hard work in bringing smiles on the faces of many. Lynn and Brewster, (2019) observed that tips are given as a kind of assistance to low income earners, among whom hotel staff are.

\section{Conclusions and Implications}

From the findings, it can be concluded that domestic tourists in Zimbabwe perceive tipping as an appropriate and good practice. The main form of tipping indicated in the study is the monetary one where guests give money as an appreciation for good service rendered. One can also conclude that the motivations for tipping are as varied as the people who practice it but the outstanding ones are (i) appreciation of excellent service, (ii) instigating a better service in the future and (iii) motivation for employees. The implications of the findings are that service providers, particularly hotels have a chance to both motivate and retain their staff member if they provide prime services. The domestic tourists, who make up the majority of tourists during times of crisis, are willing and able to give a tip to hospitality service staff and this is a great incentive for the employees. On the other hand, since most of the respondents indicated that they would give a tip for exceptional service, the reverse may be true. If the hotels and other hospitality service providers offer ordinary services, chances are that domestic tourists will not give any tip. It is therefore on the best interest of the hospitality industry in Zimbabwe to capitalize on the goodwill of the domestic market in order to retain their employees.

\section{References}

Azar, O. H., (2010). Do people tip because of psychological or strategic motivations? An empirical analysis of tipping. Applied Economics, 42(23), p. $3039-3044$.

Basera, V., (2018). Tourism Marketing Strategies and Domestic Tourism Demand in Kariba Resort (Zimbabwe). Journal of Tourism and Hospitality Management, 7(2). 
Mazhande, Basera, Chikuta, Tapfuma, Ncube and Baipai / Journal of Gastronomy, Hospitality, and Travel. 3(1) - 2020

Csey, B., (2001). Tipping in New Zealand restaurants. Hospitality Management, Volume 20, pp. 219-225.

Gorton,M. (2000) Overcoming The Structure-Agency Divide In Small Business Research. International Journal Of Entrepreneurial Behaviour \& Research, 6, pp.276-293.

Herle, F., (2018). The Impact of Destination Image on Tourists' Satisfaction and Loyalty in the Context of Domestic Tourism. MID J, 1(2).

Jahan, N., (2018). Determinants of Tipping Behavior: Evidence from US Restaurants, South Dakota: South Dakota State University.

Kabote, F., Mamimine, P. W. \& Muranda, Z., (2017). Domestic tourism for sustainable development in developing countries. African Journal of Hospitality, Tourism and Leisure, 6(2).

Kabote, F. \& Mutsena, C., (2013). Zimbabwe policy environment and domestic tourism perfomance. International Journal of Safety and Security in Tourism/Hospitality.

Kabote, F., Patrick, M. W. \& Murand, Z., (2019). A situational analysis of Zimbabwe's domestic tourists' travel trends. Cogent Social Sciences, 5(1).

Kanokanga, P. et al.,( 2014). Domestic Tourism Development and Anchor Attractions: „Tourisminge the Small Towns in Zimbabwe - The Touristse Perspectives.. Journal Of Humanities And Social Science, 19(4), pp. 54-56.

Kazembe, C. \& Mapingure, C.,( 2014). The perceptions of employees towards tipping and motivation in the hotel industry. African Journal of Hospitality, Tourism and Leisure, 3(1).

Kruger, M. \& Saayman, M., (2016). The dining and tipping behaviour of Black South Africans: A segmentation approach. Southern African Business Review , 20(1), pp. 336 - 364.

Lee, P. C. \& Dewald, B., (2016). Tipping practices of Chinese tourists in U.S. restaurants: An exploratory study. Journal of Tourism and Hospitality Management, 4(2), pp. 17 - 34.

Lynn, M., (2008). Personality and tipping, Cornell: Cornell University.

Lynn, M., (2015). Service gratuities and tipping: A motivational framework. Journal of Economic Psychology , Volume 46, pp. 74-88.

Lynn, M., (2016). The business case for (and against) restaurant tipping. Cornell Hospitality Report, 16(4), pp. 3-24.

Lynn, M. \& Brewster, Z. W., (2019). The tipping behavior and motives of US travelers abroad: affected by host nations' tipping norms?. Journal of Travel Research, pp. 1-15.

Lynn, M. \& McCall, M., (2000). Gratitude and gratuity: A meta-analysis of research on the service-tipping relationship, Cornell: Cornell University, School of Hospitality. 
Mazhande, Basera, Chikuta, Tapfuma, Ncube and Baipai / Journal of Gastronomy, Hospitality, and Travel. 3(1) - 2020

Lynn, M. \& Mynier, K., (1993). Effect of server posture on restaurant tipping. Journal of Applied Social Psychology, 23(8), pp. 678-685.

Lynn, M. \& Withiam, G., (2008). Tipping and its alternatives: Business considerations and directions for research.. Journal of Services Marketing, 46(5), pp. 573-583.

Lynn, M., Zinkhan, G. M. \& Harris, J.,( 1993). Consumer tipping: A cross-country study. Journal of Consumer Research, 20(3), pp. 478-488.

Makhaola, L. J. \& Proches, C. N. G., (2017). The Significance of Domestic Tourism in Durban, South Africa. African Journal of Hospitality, Tourism and Leisure, 6(4).

Mapingure, c., Plessis., D. \& Sayman, M.,( 2019). Travel motivations of domestic tourists: The case of Zimbabwe. African Journal of Hospitality, Tourism and Leisure, 8(2).

Mkono, M., (2011). Tipping Practices and Policies in Zimbabwe's Hotel Industry: Impacts on Restaurant Waiters' Service Delivery and Work Relationships. Journal of Foodservice Business Research, 14(4), pp. 414-425.

Nusrat, J., (2018). Determinants of Tipping Behavior: Evidence from US Restaurants, South Dakota: South Dakota University.

Raspor, A. \& Rozman, T.,( 2016). Impact of Tipping on Workers' Motivation: Comparison between the hospitality and gaming industry in Slovania.

Ritchie, J. and Lewis. J. (2003) Qualitative Research Practice: A Guide for Social Science Students and Researchers. Sage Publications, London

Saayman, M., (2014). To tip or not to tip?. African Journal of Hospitality, Tourism and Leisure , 3(2).

Saayman, M. \& Saayman, A.,( 2015). Understanding tipping behaviour - an economic perspective. Tourism Economics, 21(2), pp. 247-265.

Shatnawi, H, Najdawi B, Kanaan K, Khaleefah Q \& Khasawneh M., (2019). Factors affecting customers' behaviour towards tipping intentions in Jordanian restaurants. GeoJournal of Tourism and Geosites, Volume 26, pp. 761-768.

Sigh, S., (2009). Domestic tourism in Asia: Diversity and divergence. London: Earthscan

Suarez, D., (2009). Restaurant tipping: short-circuiting the morality of the market. Economic Development, Integration, and Morality in Asiaa nd the Americas Research in Economic Anthropology, Volume 29, pp. 307-339.

United Nations World Tourism Organisation, (2005). UNWTO Tourism Highlights-2005 Edition, Madrid, Spain: UNWTO. 
Mazhande, Basera, Chikuta, Tapfuma, Ncube and Baipai / Journal of Gastronomy, Hospitality, and Travel. 3(1) - 2020

Whaley, J. E. \& Costen, W. M., (2019). Personal and social tipping norms: race and sex differences. International journal of marketing studies, 11(3).

Zahari, M. S. M., Rashdi, M. O. \& Othman, S. M. R. Z.,( 2011). Tipping has it becoming a prevalent norms in Malaysia hospitality industry. Journal of Tourism, Hospitality and Culinary Arts, 3(3), pp. 39-52.

Zahra, S. (2007) Contextualizing Theory Building In Entrepreneurship Research. Journal Of Business Venturing, 22 (3), pp.433-452

Zakaria, H. M. \& Aziz, A., (2018). Domestic Tourist Destination Satisfaction: A Case of Kuala Selangor. Journal of Tourism, Hospitality and Environment Management, 3(9), pp. 89-103. 